\title{
STRATEGI PENGEMBANGAN USAHA ONCOM TERHADAP TENAGA KERJA PEDESAAN GUNA PENGUATAN KETAHANAN PANGAN DAN KESEJAHTERAAN MASYARAKAT
}

\author{
Pandi Pardian, Dhany Esperanza, dan Eliana Wulandari \\ Jurusan Sosial Ekonomi Pertanian Universitas Padjadjaran \\ Jalan Raya Jatinangor Km.21 Bandung 40191, \\ Email: pandip3@gmail.com
}

\begin{abstract}
ABSTRAK. Penelitian ini berjudul Strategi Pengembangan Usaha Oncom Terhadap Tenaga Kerja Pedesaan Guna Penguatan Ketahanan Pangan dan Kesejahteraan Masyarakat. Penelitian ini dilakukan dengan tujuan mengidentifikasi dan menganalisis lingkungan internal dan eksternal strategi pengembangan usaha oncom terhadap tenaga kerja pedesaan, merumuskan strategi yang dapat digunakan dalam meningkatkan minat tenaga kerja pedesaan dan memberikan rekomendasi strategi guna pengembangan usaha oncom di Desa Pasireungit. Metode survey yang dilakukan adalah dengan purposive sampling method dan analisa pengumpulan data menggunakan matrik IFE dan EFE, sedangkan proses pencocokan data menggunakan matrik IE kemudian pengambilan keputusan strategi yang dipilih digunakan matrik QSPM dan SWOT. Dari hasil analisa dan pengolahan data dapat disimpulkan hasil penelitian strategi pengembangan usaha oncom dilakukan dengan divesifikasi produk, pengembangan produk, pengembangan pasar dan penetrasi pasar yang dilakukan dengan mempertahankan oncom dari kacang tanah dan memperbaiki kualitas, pemberian kredit usaha, adanya pasar yang jelas dan pembuatan sentra pemasaran oncom di gerbang Desa Pasireungit, adanya pelatihan pembuatan aneka produk olahan dari bahan baku oncom, serta adanya legalitas usaha dan produk yang dihasilkan.
\end{abstract}

Kata Kunci : Oncom, Desa Pasireungit, Strategi Bisnis, Tenaga Kerja Pedesaan

\section{ONCOM BUSINESS DEVELOPMENT STRATEGY TOWARDS RURAL WORKFORCE IN AN EFFORTS TO STRENGTHEN FOOD SECURITY AND SOCIETY WELFACE}

\begin{abstract}
This research was conducted with the goal to identify and analyze the internal and external environment of oncom business development strategy towards rural workforce, to formulate strategy that can be used to increase rural workforce interest and to provide the strategy recommendation for the oncom business development in Pasireungit Village. Survey method used in this research is purposive sampling, data collecting analysis uses IFE and EFE matrix, while the
\end{abstract}


data matching uses IE matrix, as for strategic decision making uses QSPM and SWOT matrix. From the result of data processing and analyze can be concluded that the best strategy for oncom business strategy is product divesifikacation, product development, market development and market penetration that implemented by oncom quality development, provide the business capital, crated oncom market centre at the gate of Pasireungit Village, created training to make various product from oncom as raw material and than product and business legal.

Keywords: Oncom, Pasireungit Village, Business Strategy, Rural Workforce

\section{PENDAHULUAN}

Adanya globalisasi dan perdagangan bebas terutama Asean China Free trade (ACFTA) saat ini masih menjadi perhatian semua pihak saat ini tidak terkecuali bagi para penggerak di bidang UMKM (usaha mikro, kecil dan menengah). Menurut Siregar, Faisal O (2010), sektor UMKM (usaha mikro, kecil dan menengah) memiliki peranan yang strategis dalam menopang perekonomian Jawa Barat karena jumlahnya yang cukup banyak dan memberikan kontribusi lebih dari $60 \%$ dalam terhadap pembentukan PDRB Jawa Barat serta berkontribusi dalam penterapan tenaga kerja yang cukup besar.

Desa Pasireungit Kecamatan Paseh Kabupaten Sumedang Provinsi Jawa Barat telah lama dikenal sebagai sentra pembuatan oncom di Kabupaten Sumedang. Oncom merupakan salah satu makanan khas Jawa Barat terutama Sumedang dan telah lama dikenal dan diusahakan oleh masyarakat terutama masyarakat Desa Pasireungit bahkan semenjak tahun 1942, salah satu usaha oncom yang telah lama di kenal di Desa Pasireungit adalah oncom popas (perusahaan oncom pasireungit asli) yang dirintis oleh bapak Empu, namun saat ini perkembangan usaha tersebut kurang begitu dilirik apalagi oleh tenaga kerja pedesaan. Usaha oncom yang ada di Desa Pasireungit bahkan bisa dikatakan hanya melajutkan usaha yang sudah ada dari orangtua tanpa ada inovasi dan strategi usaha yang baik untuk mengembangkannya. Besarnya potensi usaha pembuatan oncom ini tanpa diimbangi dengan strategi mengembangan usaha akan menyebabkannya kalah bersaing sehingga bisa jadi citra Desa Pasireungit sebagai penghasil oncom akan pudar apalagi terkait dengan globalisasi yang mempengaruhi hampir semua bidang termasuk terhadap keberadaan usaha mikro, kecil dan menengah. Selama ini usaha mikro, kecil dan menengah sebelum adanya ACFTA masih belum bisa berkembang dan bersaing sehingga mempunyai posisi tawar yang kurang menguntungkan. AFCTA membuat terjadinya transformasi struktur perekonomian nasional dan pendapatan masyarakat melalui berbagai transformasi ketenagakerjaan kemudian diikuti oleh perubahan pola konsumsi masyarakat. Hal ini secara langsung maupun tidak langsung akan mempengaruhi usaha oncom Desa Pasireungit yang menuntut usaha oncom melakukan langkah-langkah strategis agar bisa tetap bertahan dan 
memanfaatkannya menjadi peluang sehingga bisa tumbuh dan berkembang secara alamiah dan berkelanjutan.

Ini merupakan sebuah tantangan bagi keberadaan usaha oncom yang termasuk usaha mikro, kecil dan menengah yang diusahakan secara tradisional atau usaha keluarga dan tidak padat modal untuk tetap mampu hidup dan tetap bertahan serta berkembang menghadapi kondisi tersebut. Melihat hal tersebut membuat peneliti tertarik untuk mengkaji strategi pengembangan usaha oncom terhadap tenaga kerja pedesaaan guna peningkatkan ketahanan pangan dan kesejahteraan masyarakat.

\section{METODE}

Penelitian ini dilakukan di Desa Pasireungit Kecamatan Paseh Kabupaten Sumedang dengan menggunakan metode studi kasus (case study). Menurut Moehar, Daniel (2005), penelitian studi kasus merupakan salah satu penelitian deskriptif yang bertujuan untuk mempelajari latar belakang keadaan sekarang dan interaksi lingkungan dari suatu unit sosial secara lebih mendalam atas suatu peristiwa yang dipandang sebagai suatu kesatuan.

\section{Jenis dan Sumber Data}

Data yang digunakan dalam penelitian ini adalah data primer dan data sekunder. Dimana pada proses penggalian data tersebut dilakukan sebagai berikut :

1. Data primer yang diperoleh dengan teknik wawancara kepada responden yang ditentukan secara sengaja (purposive sampling method) dengan menggunakan panduan wawancara

2. Data sekunder, diperoleh dari instansi terkait dengan penelitian ini dan juga dari jurnal dan hasil penelitan yang terkait dengan penelitian ini.

\section{Teknik Pengumpulan Data}

Teknik pengumpulan data atau informasi bertujuan untuk memperoleh data yang diinginkan dan dibutuhkan dalam penelitian. Data yang diperlukan dalam penelitian ini dikumpulkan melalui: pengamatan (observasi), wawancara (interview), kuesioner dan studi literatur.

\section{Pengolahan dan Analisis Data}

Pengolahan data dan informasi yang diperoleh di lapangan dilakukan secara manual dan dianalisis dengan metode analisis strategi yang menurut David, Fred $\mathrm{R}$ (2004) terdiri dari tahapan :

\section{Pengumpulan data (input stage)}

Pada tahapan pengumpulan data, data yang dikumpulkan adalah data internal dan eksternal usaha oncom terhadap tenaga kerja pedesaan. Pada tahap ini dilakukan analisis IFE (internal factor evaluation) atau IFAS (internal factor analysis summary) dan EFE/EFAS (external factor evaluation/external factor analysis summary) dimana matrik IFE/IFAS digunakan untuk mengidentifikasikan faktor- 
faktor internal sedangkan matrik EFE/EFAS digunakan untuk mengidentifikasikan faktor-faktor eksternal. Menurut Rangkuti, F (2000) dalam pembuatan matrik IFE dan EFE pembobotan matrik IFE berkisar antara 1,00 sampai 4,0 dengan rata-rata 2,5 dan jika skor bobot $<2,5=$ kondisi internal usaha/organisasi lemah, $>2,5=$ internal usaha/organisasi kuat. Pada matrik EFE pembobotan matrik berkisar antara 1,00 sampai 4,0 dengan rata-rata 2,5 dan jika skor bobot sama dengan 4,00 menunjukkan usaha/organisasi mampu merespon peluang untuk menghindari ancaman dengan baik, sedangkan jika total skor 1,00 berarti usaha/organisasi tidak mampu memanfaatkan peluang yang dihadapi dengan baik.

Bentuk penilaian pembobotan terdiri dari penilaian bobot faktor strategis internal dan penilaian bobot faktor strategis eksternal usaha kecil oncom desa Pasireungit digambarkan sebagai berikut:

Tabel 1. Penilaian bobot faktor strategis internal maupun eksternal usaha oncom

\begin{tabular}{|c|c|c|c|c|}
\hline $\begin{array}{l}\text { Faktor Strategis } \\
\text { Internal/Eksternal }\end{array}$ & A & B & ... & Total \\
\hline A & & & & $X i$ \\
\hline \multicolumn{5}{|l|}{$B$} \\
\hline \multicolumn{5}{|l|}{$\ldots$} \\
\hline Total & & & & $\sum_{i=1}$ \\
\hline
\end{tabular}

Sumber : David (2004)

Bobot pada setiap vaiabel diperoleh dengan menentukan nilai setiap variabel terhadap jumlah keseluruhan variabel dengan menggunakan rumus :

$$
a_{i}=\frac{x_{i}}{n} \text { dimana : }
$$

$a_{i}=$ bobot variabel $k e-i ; X_{i}=$ nilai Variabel $k e-i ; i=1,2,3, \ldots$ dan $n=$ jumlah variabel.

\section{Tahap analisis pencocokan (matching stage)}

Pada tahapan ini semua informasi yang didapat dari tahap pertama di analisis dengan model matrik IE (internal dan eksterna). Menurut David, Fred R (2004) matrik IE dibagi menjadi sembilan sel dan dibagi menjadi tiga bagian utama dan memiliki dampak strategis yang berbeda yaitu :

1. Strategi tumbuh dan bina yang terdiri dari sel I, II, IV. Strategi intensif (penetrasi pasar, pengembangan pasar dan produk) atau integrative (integrasi ke belakang, depan dan horizontal) 
2. Strategi pertahanan dan pelihara yang terdiri sel III, V, VII. Strategi penetrasi pasar dan pengembangan produk banyak dipakai

3. Strategi panen atau divestasi yang terdiri dari sel VI, VIII, IX

\section{Tahap Pengambilan Keputusan (decision stage)}

Pada tahapan ini digunakan matrik QSPM (Quantitative Strategic Planning Matrix) untuk pengambilan keputusan dengan mengevaluasi dan memilih strategi yang paling baik dan cocok dengan lingkungan internal dan eksternal usaha /organisasi. Alternative strategi yang memiliki nilai total terbesar pada matriks QSPM merupakan strategi yang paling baik.

\section{HASIL DAN PEMBAHASAN}

Lingkungan Internal dan Eksternal Pengembangan Usaha Oncom Terhadap Tenaga Kerja Pedesaaan

Oncom

Oncom merupakan makanan khas Jawa Barat yang terbuat dari kacang tanah dengan tambahan onggok yang di ragikan sehingga berjamur dan dimanfaatkan langsung sebagai bahan makanan ataupun sebagai bahan tambahan makanan dan juga bahan baku untuk membuat aneka makanan olahan lainnya. Proses produksi oncom sampai menjadi oncom melalui 12 tahapan seperti digambarkan berikut:

\begin{tabular}{|c|c|c|}
\hline $\begin{array}{l}\text { 1. Kacang di sortir } \\
\text { terlebih dahulu }\end{array}$ & $\begin{array}{l}\text { 2. Kacang di giling atau } \\
\text { di haluskan }\end{array}$ & $\begin{array}{l}\text { 3. Kacang kukus kurang } \\
\text { lebih } 10 \text { menit agar } \\
\text { kacang menjadi lunak }\end{array}$ \\
\hline $\begin{array}{l}\text { 6. Kemudian bungkil } \\
\text { di potong potong } \\
\text { atau di hancurkan }\end{array}$ & $\begin{array}{l}\text { 5. Bungkil di press } \\
\text { untuk mengeluarkan } \\
\text { minyak agar bungkil } \\
\text { menjadi keras }\end{array}$ & $\begin{array}{l}\text { 4. Di cetak menjadi } \\
\text { bungkil berbentuk bulat } \\
\text { dengan diameter kurang } \\
\text { lebih } 20-30 \mathrm{~cm}\end{array}$ \\
\hline $\begin{array}{l}\text { 7. Di rendam dari } \\
\text { jam } 7 \text { pagi sampai } \\
\text { jam } 3 \text { sore atau } \\
\text { sekitar } 7-8 \text { jam }\end{array}$ & $\begin{array}{l}\text { 8. Angkat bungkil } \\
\text { dalam rendaman dan } \\
\text { dinginkan }\end{array}$ & $\begin{array}{l}\text { 9. Jam } 12 \text { malam } \\
\text { bungkil dicampur rata } \\
\text { dengan ongok sesuai } \\
\text { takaran }\end{array}$ \\
\hline $\begin{array}{l}\text { 12. Biarkan selama } \\
24 \text { jam hingga } \\
\text { muncul jamur } \\
\text { sehingga menjadi }\end{array}$ & $\begin{array}{l}\text { 11. Potongan oncom } \\
\text { diberi/ditaburi ragi } \\
\text { secukupnya }\end{array}$ & $\begin{array}{l}\text { 10. Dicetak menjadi } \\
\text { oncom persegi } \\
\text { berukuran } 10 \times 25 \mathrm{~cm}\end{array}$ \\
\hline
\end{tabular}

Gambar 1. Tahapan proses pembuatan oncom 


\section{Tenaga Kerja Pedesaaan}

Menurut undang-undang ketenagakerjaan no 13 tahun 2003, tenaga kerja adalah setiap orang yang mampu melakukan pekerjaan guna menghasilkan barang dan atau jasa baik untuk memenuhi kebutuhan sendiri maupun untuk masyarakat. Tenaga kerja merupakan salah satu faktor produksi yang dapat mempengaruhi hasil produksi baik kualitas maupun kuantitas produk. Menurut badan pusat statistik (BPS ) batasan usia tenaga kerja muda adalah 15-34 tahun. Sedangkan tenaga kerja pedesaan dalam penelitian ini dimaksudkan adalah tenaga kerja yang terdapat di desa dan berusia 15-34 tahun. Tenaga kerja yang terdapat di Desa Pasireungit dengan kisaran usia 15- 34 tahun pada tahun 2009 kurang lebih sebanyak 3375 orang. Untuk data ketenagakerjaan di Desa pasireungit disajikan sebagai berikut:

Tabel 2. Jumlah Tenaga Kerja, Pencari Kerja, dan Lowongan Kerja Di Desa Pasireungit Tahun 2009

\begin{tabular}{clcc}
\hline No & & Yang Terdaftar & Jumlah \\
\hline 1 & Pencari Kerja & 3.374 \\
\hline 2 & Yang Ditempatkan & 964 \\
\hline 3 & Lowongan Kerja & 739 \\
\hline 4 & Sisa Pencari Kerja & 3.374
\end{tabular}

Sumber : Data Desa Pasireungit

Dari tabel terlihat bahwa jumlah lowongan keja yang ada belum cukup atau mampu menampung semua pencari kerja yang ada sehingga masih banyaknya pencari kerja di Desa Pasireungit. Sedangkan usaha oncom bagi tenaga kerja Desa Pasireungit merupakan usaha turun temurun dan sudah dikenal dan membudaya namun karena keterbatasan pengetahuan bagaimana mengolah oncom menjadi aneka produk olahan lainnya serta keterbatasan modal membuat tenaga kerja kurang tertarik, di satu sisi sangat disayangkan jika perkembangan usaha oncom semakin berkurang karena oncom merupakan image Desa Pasireungit sejak lama terutama di Kabupaten Sumedang.

\section{Analisis Lingkungan Internal}

Analisis lingkungan internal dilakukan untuk mengetahui kekuatan dan kelemahan usaha oncom ditinjau dari internal organisasi. Dari analisis lingkungan internal ini didaptkan beberapa komponen yang menjadi kekuatan dan kelemahan usaha oncom diantaranya: 
Tabel 3. Kekuatan dan kelemahan usaha oncom

\begin{tabular}{|c|c|c|c|c|}
\hline Faktor Internal & & Kekuatan & & Kelemahan \\
\hline $\begin{array}{l}\text { Sumberdaya } \\
\text { Manusia }\end{array}$ & $>$ & $\begin{array}{l}\text { Keharmonisan hubungan } \\
\text { antar pemilik dan pekerja } \\
\text { Mudah mendapatkan } \\
\text { tenaga kerja }\end{array}$ & $>$ & $\begin{array}{l}\text { Tingkat pendidikan masih } \\
\text { rendah }\end{array}$ \\
\hline $\begin{array}{l}\text { Keuangan dan } \\
\text { Akuntasi }\end{array}$ & $>$ & Modal yang diperlukan kecil & $>$ & $\begin{array}{l}\text { Keterbatasan dalam } \\
\text { pencatatan keuangan }\end{array}$ \\
\hline \multirow{4}{*}{ Produksi dan Operasi } & & $\begin{array}{l}\text { Harga produk relatif murah } \\
\text { dibandingkan oncom } \\
\text { dengan bahan sejenis }\end{array}$ & $>$ & $\begin{array}{l}\text { Penggunaan alat produksi } \\
\text { yang masih sederhana }\end{array}$ \\
\hline & $>$ & $\begin{array}{l}\text { Produk berkualitas dan } \\
\text { khas } \\
\text { Produk sudah lama dikenal }\end{array}$ & $>$ & $\begin{array}{l}\text { Belum memiliki ijin P-IRT } \\
\text { untuk oncom tapi hanya } \\
\text { produk olahan oncom }\end{array}$ \\
\hline & $>$ & $\begin{array}{l}\text { Proses pengolahan yang } \\
\text { mudah \& memiliki standar } \\
\text { produksi yang baku }\end{array}$ & $>$ & $\begin{array}{l}\text { Produk belum memilik } \\
\text { hak paten }\end{array}$ \\
\hline & & & $>$ & Kurangnya inovasi produk \\
\hline \multirow[t]{3}{*}{ Pemasaran } & $>$ & Segmentasi pasar yang luas & $>$ & $\begin{array}{l}\text { Daerah pemasaran masih } \\
\text { terbatas }\end{array}$ \\
\hline & & & $>$ & $\begin{array}{l}\text { Letaknya kurang strategis } \\
\text { Kurang informasi pasar }\end{array}$ \\
\hline & & & $>$ & $\begin{array}{l}\text { Kemasan produk yang } \\
\text { relatif sederhana }\end{array}$ \\
\hline
\end{tabular}

Dari analisis faktor-faktor strategis lingkungan internal kekuatan terbesar usaha oncom Desa Pasireungit adalah produk sudah lama dikenal dengan nilai 0,228 dan produknya berkualitas dalam artian produknya asli dari kacang tanah dengan nilai 0,192 namun selain kekuatan tersebut kelemahan terbesarnya adalah pada daerah pemasarannya yang masih terbatas dengan nilai 0,179 dan kurangnya informasi pasar dengan nilai 0,171.

Hasil analisis matriks IFE pada usaha Oncom ini yang meliputi seluruh faktor kunci internal (kekuatan dan kelemahan) mempunyai nilai sebesar 2,410. Total nilai tersebut menunjukkan bahwa usaha Oncom ini berada pada level ratarata di dalam kekuatan internal seluruhnya, sehingga usaha ini dituntut lebih optimal dalam memanfaatkan kekuatan yang dimiliki serta mereduksi kelemahan yang ada dalam mencapai keberhasilan usahanya.

\section{Analisis Lingkungan Eksternal}

Analisis lingkungan eksternal dilakukan untuk mengidentifikasikan peluang dan ancaman yang mungkin dihadapi oleh usaha oncom dengan kombinasi 
Strategi Pengembangan Usaha Oncom Terhadap Tenaga Kerja Pedesaan Guna Penguatan Ketahanan Pangan dan Kesejahteraan Masyarakat (Pandi Pardian, Dhany Esperanza, dan Eliana Wulandari)

dari masukan tenaga kerja pedesaan. Berikut beberapa komponen yang didapatkan berdasarkan hasil penelitian yaitu :

Tabel 4. Peluang dan ancaman usaha oncom

\begin{tabular}{|c|c|c|c|}
\hline Faktor Eksternal & & Peluang & Ancaman \\
\hline Demografi & $>$ & $\begin{array}{ll}\text { Populasi } & \text { penduduk } \\
\text { meningkat } & \end{array}$ & $\begin{array}{l}\text { Desa Pasireungit } \\
\text { susah di jangkau dan } \\
\text { bukan berada di } \\
\text { pinggir jalan }\end{array}$ \\
\hline Ekonomi & $>$ & $\begin{array}{l}\text { Adanya kredit bagi usaha } \\
\text { kecil } \\
\text { Jalur Utama menuju } \\
\text { kota/kabupaten lain, } \\
\text { mampu membangkitkan } \\
\text { sektor industri makanan. }\end{array}$ & $\begin{array}{l}\text { Harga bahan baku } \\
\text { yang semakin } \\
\text { meningkat }\end{array}$ \\
\hline $\begin{array}{l}\text { Kekuatan tawar } \\
\text { menawar pembeli }\end{array}$ & & & $\begin{array}{l}\text { Bargaining position } \\
\text { pembeli kuat }\end{array}$ \\
\hline $\begin{array}{l}\text { Kekuatan tawar } \\
\text { menawar pemasok }\end{array}$ & $>$ & $\begin{array}{l}\text { Terbinanya kerjasama } \\
\text { dengan pemasok Kacang } \\
\text { dari Cirebon dan Ganeas } \\
\text { dan juga pemasok onggok } \\
\text { (ampas tahu) lebih baik }\end{array}$ & \\
\hline $\begin{array}{l}\text { Persaingan diantara } \\
\text { pesaing yang ada }\end{array}$ & & & $\begin{array}{l}\text { Jaringan pemasaran } \\
\text { pesaing lebih luas } \\
\text { Adanya usaha oncom } \\
\text { dari ampas tahu } \\
\text { tanpa kacang tanah } \\
\text { yang lebih murah } \\
\end{array}$ \\
\hline $\begin{array}{l}\text { Ancaman } \\
\text { pendatang baru }\end{array}$ & & $\begin{array}{l}\text { Mambuat aneka makanan } \\
\text { olahan lain dari bahan baku } \\
\text { Oncom }\end{array}$ & $\begin{array}{l}\text { Tidak ada hambatan } \\
\text { bagi pendatang baru } \\
\text { untuk memasuki } \\
\text { industri }\end{array}$ \\
\hline
\end{tabular}

Dari hasil analisis faktor-faktor strategis eksternal yang ditunjukkan dengan matrik EFE, peluang terbesar dan perlu menjadi perhatian adalah membuat aneka olahan oncom dengan nilai 0,427 kemudian populasi penduduk yang meningkat dengan nilai 0,368 dan perlu adanya kredit untuk usha kecil oncom dengan nilai 0,312 . Sedangkan ancaman terbesarnya adalah adanya produk oncom murah dengan memanfaatkan ampas tahu dengan nilai 0,294 dan juga tidak adanya hambatan bagi pendatang baru untuk membuat usaha sejenis dan bersaing pada pasar yang sama dengan nilai 0,294 serta ancaman lainnya yaitu 
Desa Pasireunngit susah dijangkau dan bukan berada di pinggir jalan sengan nilai 0,249 .

Hasil analisis matriks EFE pada usaha Oncom yang meliputi seluruh faktor kunci eksternal (peluang dan ancaman) adalah nilai skor sebesar 3,101. Total nilai tersebut menunjukkan bahwa perusahaan berada pada level yang cukup tinggi untuk menjalankan strategi yang memanfaatkan peluang eksternal atau menghindari ancaman yang ada dalam mencapai keberhasilan usahanya.

\section{Pengembangan Usaha Oncom Untuk Menarik Minat Tenaga Kerja Pedesaan}

Dari matriks IFE dan EFE dibuat matrik IE (nternal eksternal) yang menunjukkan bahwa analisa strategi pengembangan usaha oncom berada pada kuadran ke II (dua) yaitu tumbuh dan bina seperti digambarkan berikut:

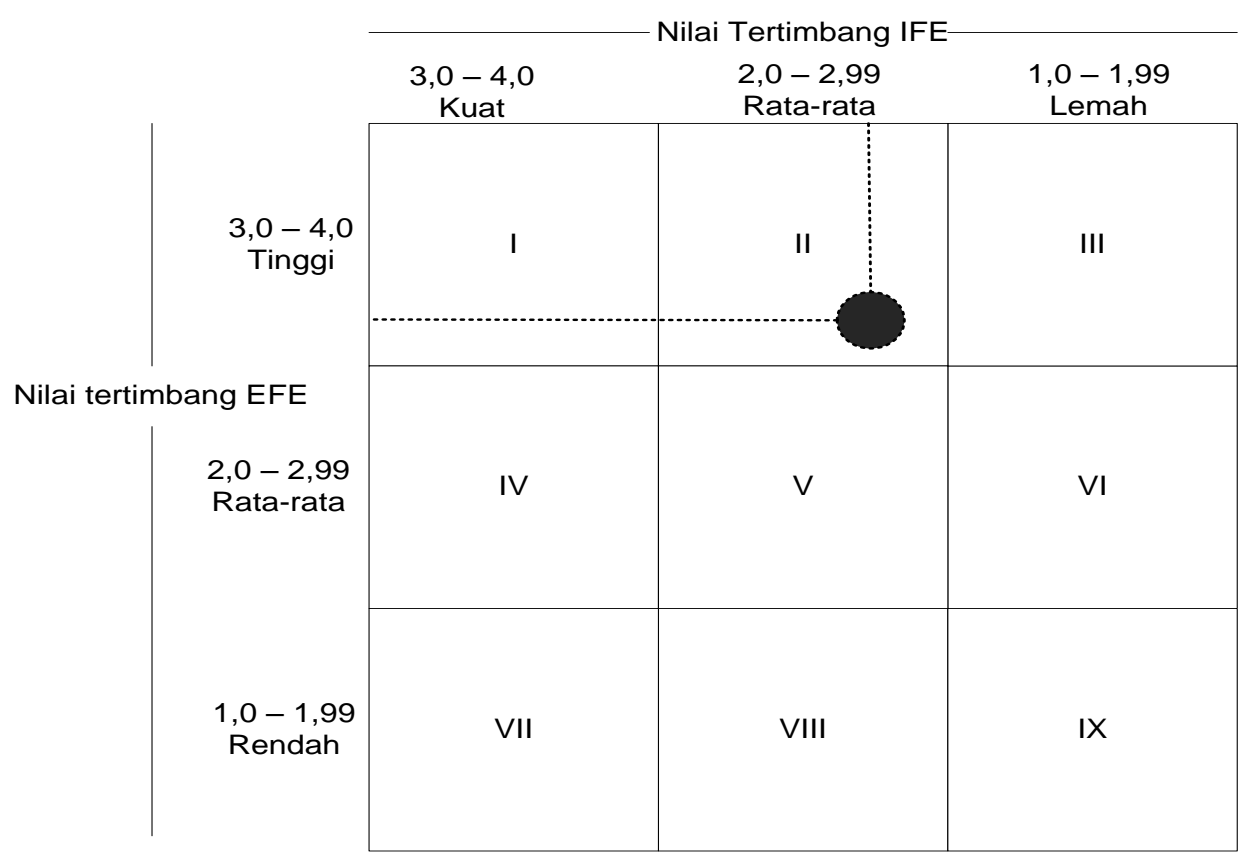

Gambar 2. Matrik internal dan eksternal usaha oncom

Dimana strategi yang diterapkan pada kuadran tersebut adalah strategi insentif (penetrasi pasar, pengembangan pasar dan pengembangan produk dan diversifikasi produk). Analisa dengan menggunakan matrik QSPM (quantitative strategic planning matrik), strategi terbaik yang dilakukan dalam mengembangkan usaha oncom yang menarik minat tenaga kerja pedesaan adalah sebagai berikut: 
1. Strategi diversifikasi produk dengan nilai 1,1629 yaitu dengan strategi penambahan produk baru baik bentuk maupun kemasan oncom yang dihasilkan.

2. Strategi pengembangan produk dengan nilai 0,962 yaitu strategi yang dilakukan guna meningkatkan penjualan akan produk dengan desain ulang ataupun modifikasi produk yang sudah ada dengan membuat aneka produk olahan dengan berbahan dasar oncom

3. Strategi pengembangan pasar dengan nilai 0,907 yaitu strategi dengan sasaran mengenalkan produk ke lokasi atau daerah baru.

4. Strategi penetrasi pasar dengan nilai 0,7216 yaitu strategi guna meningkatkan pangsa pasar produk yang sudah ada dengan melakukan usaha pemasaran yang lebih intensif

\section{Pengembangan Usaha Oncom di Desa Pasireungit}

\section{Ketahanan Pangan}

Menurut FAO (1996) dalam PPK-LIPI (No. 56/2004) indikator ketahanan pangan terdiri dari kecukupan ketersedian pangan, stabilitas ketersediaan pangan, aksesibilitas ketersediaan pangan dan kualitas/keamanan pangan. Dimana kecukupan dan stabilitas ketersediaan pangan didasarkan pada ketesedian beras dalam rumah tangga selama 1 tahun dengan batasan tidak ada persediaan, tersedia $1-102 \mathrm{~kg}$, dan $>102 \mathrm{~kg}$, sedangkan stabilitas didasarkan pada frekuensi makan dengan kriteria 1, 2, 3 kali sehari dan lebih besar dari 3 kali sehari, aksesibilitas pangan dengan acuan berdasakan cara memperoleh bahan makanan yaitu dari memproduksi atau dari membeli, sedangkan kualitas pangan didasarkan atas konsumsi berupa protein hewani dan nabati. Kombinasi dari ke empat kriteria diatas menghasilkan indikator ketahanan pangan untuk melihat kategori rumah tangga dari tenaga kerja usaha oncom tersebut. Ketahanan pangan dalam penelitian ini dikaitkan dengan pendapatan yang didapatkan tenaga kerja usaha oncom dan dikonversikan untuk memenuhi indikator ketahanan pangan oleh tenaga kerja usaha oncom Popas dan $\mathrm{Hj}$. Amar. Tenaga kerja usaha oncom dibedakan menjadi 4 yaitu: tenaga kerja pencetak, tenaga kerja kasar (harian), Tenaga kerja Sortir dan Pengantar (sopir) dengan perhitungan pendapatan sebagai berikut: 
Tabel 5. Jenis pekerjaan dan pendapatan tenaga kerja usaha oncom

\section{No Jenis Pekerjaan Tenaga Kerja}

Upah Tenaga Kerja per orang per bulan dengan 28 hari kerja

\begin{tabular}{lll}
\hline 1 & Pencetak & $147000-342300$ \\
\hline 2 & Tenaga Kerja Kasar & $980000-1400000$ \\
\hline 3 & Tenaga Kerja Sortir & $280000-420000$ \\
\hline 4 & Supir & $700000-980000$ \\
\hline
\end{tabular}

Dari analisa indikator ketahanan pangan diketahui, ketahanan pangan rumah tangga tenaga kerja usaha oncom dari penghasilan yang didapatkan diperlihatkan dengan indeks ketahan pangan berikut:

Tabel 6. Indeks ketahanan pangan tenaga kerja usaha oncom

\begin{tabular}{lccc}
\hline \multirow{2}{*}{$\begin{array}{c}\text { Kontinyuitas } \\
\text { ketersediaan } \\
\text { pangan }\end{array}$} & $\begin{array}{c}\text { Kulitas/keamanan pangan: Konsumsi protein hewani } \\
\text { dan/atau nabati }\end{array}$ \\
\cline { 2 - 4 } & $\begin{array}{c}\text { Pan hewani } \\
\text { nabati/protein } \\
\text { hewani saja }\end{array}$ & $\begin{array}{c}\text { Protein } \\
\text { nabati } \\
\text { saja }\end{array}$ & $\begin{array}{c}\text { Tidak ada konsumsi } \\
\text { protein hewani, dan } \\
\text { nabati }\end{array}$ \\
\hline Total (TK Pencetak Oncom + TK. Kasar + TK. Sortir + TK Supir) \\
\hline Kontinyu & $85 \%$ & $0 \%$ & $0 \%$ \\
\hline Kurang kontinyu & $15 \%$ & $0 \%$ & $0 \%$ \\
\hline Tidak kontinyu & $0 \%$ & $0 \%$ & $0 \%$ \\
\hline
\end{tabular}

Indeks ketahanan pangan tersebut menyimpulkan bahwa rata-rata tenaga kerja yang bekerja di usaha pembuatan oncom sebagian besar termasuk dalam kategori rumah tangga tahan pangan dengan presentase $85 \%$ dan rumah tangga kurang tahan pangan $15 \%$.

\section{Kesejahteraan Masyarakat}

Kesejahteraan tenaga kerja usaha oncom tidak terlepas dari indeks ketahanan pangan, sedangkan kesejahteraan masyarakat terkait dengan usaha oncom tidak lepas dari penyerapan tenaga kerja dalam kegiatan usaha oncom dan indeks ketahanan pangan. Jumlah kebutuhan dan jenis tenaga kerja untuk tiap usaha oncom berbeda tergantung besarnya usaha tersebut namun dari penelitian untuk usaha oncom kategori kecil bisa diperlihatkan sebagai berikut: 
Tabel 7. Jenis pekerjaan, jumlah dan jenis kelamin tenaga kerja usaha oncom

\begin{tabular}{clcc}
\hline No & $\begin{array}{c}\text { Jenis Pekerjaan } \\
\text { Tenaga Kerja }\end{array}$ & $\begin{array}{c}\text { Jumlah Tenaga } \\
\text { Kerja }\end{array}$ & $\begin{array}{c}\text { Gender Tenaga } \\
\text { Kerja }\end{array}$ \\
\hline 1 & Pencetak & $2-4$ orang & Wanita \\
\hline 2 & Tenaga Kerja Kasar & $1-3$ Orang & Pria \\
\hline 3 & Tenaga Kerja Sortir & $1-2$ Orang & Wanita \\
\hline 4 & Supir & 1 Orang & Pria \\
\hline
\end{tabular}

Untuk tenaga kerja kasar, sortir dan supir melakukan pekerjaanya pada siang hari (full time) dan sebaliknya tenaga kerja pencetak yang kebanyakan wanita dilakukan pada malam hari dan paruh waktu. Jika dilihat dari faktor tenaga kerja dan penghasilan, tingkat kesejahteraan masyarakat di Desa Pasireungit tidak terlepas dari jumlah pencari kerja yang ada. Untuk tahun 2009 penyerapan tenaga kerja hanya sebanyak 964 orang dan sisa pencari kerja 3374 orang sedangkan tahun 2010 jumlah pencari kerja di Desa Pasireungit adalah sebanyak 4364 orang dengan rincian laki-laki sebesar 1.719 orang dan pencari kerja perempuan sebanyak 1.655 orang. Dari segi pendidikan, lulusan SLTA menempati urutan tertinggi dari jumlah persentase pencari kerja yang berhasil ditempatkan terhadap total pencari kerja, yaitu menurut tingkat pendidikan mencapai angka $55 \%$. Saat ini usaha oncom yang cukup dikenal dan berproduksi kontinyu hanya oncom popas dan $\mathrm{Hj}$. Amar. Pengembangan usaha oncom akan menimbulkan lapangan kerja sehingga mampu mengurangi pengangguran dan meningkatkan pendapatan keluarga serta kesejahteraan masyarakat pada umumnya.

\section{Rekomendasi Strategi Pengembangan Usaha Oncom Di Desa Pasireungit}

Usaha oncom mempunyai potensi yang besar untuk meningkatkan ketahanan pangan dan kesejahteraan masyarakat Desa Pasireungit jika strategi pengembangan usaha oncom dikelola dan dijalankan dengan baik. Melihat dari indeks ketahanan pangan tenaga kerja usaha oncom saat ini masih cukup baik namun belum tentu kedepan akan tetap karena berbagai hal yang mempengaruhi usaha oncom tersebut baik secara internal dan eksternal yang bisa membuat usaha berkembang atau bahkan sebaliknya. Oleh sebab itu, menurut Rangkuti (2000), analisis SWOT (stength, weakness, opportunity, tardiness) merupakan cara sistematis untuk mengidentifikasikan faktor-faktor dan strategi yang menggambarkan kesesuaian paling baik diantara berbagai alternatif strategi yang ada. Berdasarkan matriks QSPM dibuat analisa SWOT untuk memunculkan rekomendasi strategi pengembangan usaha oncom Desa Pasireungit terhadap tenaga kerja pedesaaan guna penguatan ketahan pangan dan kesejahteraan masyarakat. Rekomendasi strategi tersebut adalah: 
1. Strategi kekuatan - peluang yaitu mempertahankan oncom dari kacang tanah dan memperbaiki kualitas dan pemberian kredit usaha

2. Strategi kekuatan - ancaman yaitu adanya pasar yang jelas dan pembuatan sentra pemasaran oncom di gerbang Desa Pasireungit.

3. Strategi kelemahan - peluang yaitu adanya pelatihan pembuatan aneka produk olahan dari bahan baku oncom sehingga produsen oncom bisa berkembang dan menyerap tenaga kerja.

4. Strategi kelemahan - ancaman yaitu adanya legalitas usaha dan produk yang dihasilkan perlu dilakukan untuk lebih meningkatkan kepercayaan dan image produk yang dihasilkan.

Strategi tersebut menuntut peran serta berbagai pihak tidak hanya pengusaha, masyarakat dan pemerintah desa namun juga keterlibatan pemerintah kabupaten dengan dinas terkait yang terintegrasi guna membantu menggerakkan usaha oncom sebagai brand Desa Pasireungit dan aneka produk olahannya sehingga berdaya dan menimbulkan lapangan kerja guna meningkatkan kesejahteraan masyarakat. .

\section{SIMPULAN}

Lingkungan internal strategi pengembangan usaha oncom terhadap tenaga kerja kerja pedesaan mengungkapkan faktor strategis internal yaitu sumberdaya manusia, keuangan dan akuntansi, produksi dan operasi dan pemasaran dengan nilai IFE 2,410. Sedangkan lingkungan eksternal mengungkapkan faktor strategis eksternal yaitu demografi, ekonomi, kekuatan tawar pembeli, kekuatan tawar pemasok, persaingan diantara pesaing yang ada dan ancaman pendatang baru dengan nilai EFE 3,101

Strategi dalam pengembangan usaha oncom yang menarik minat tenaga kerja pedesaan berada pada kuadran II (strategi tumbuh dan bina) dengan implementasi strategi adalah penerapkan strategi diversifikasi produk, pengembangan produk, pengembangan pasar dan penetrasi pasar yang diinplementasikan dengan membuat aneka jenis oncom dan produk olahan berbahan dasar oncom serta membuat pasar baru dan pemasaran yang lebih intensif.

Untuk meningkatkan ketahanan pangan dan minat serta penyerapan tenaga kerja guna meningkatkan kesejahteraan masyarakat maka rekomendasi strategi pengembangan usaha oncom di Desa Pasireungit dilakukan dengan memanfaatkan kekuatan dan peluang yang ada untuk meminimalkan ancaman dan kelemahan yaitu mempertahankan oncom dari kacang tanah dan memperbaiki kualitas, pemberian kredit usaha, adanya pasar yang jelas dan pembuatan sentra pemasaran oncom gerbang Desa Pasireungit, adanya pelatihan pembuatan aneka produk olahan dari bahan baku oncom, serta adanya legalitas usaha dan produk yang dihasilkan menuntut peran serta pemerintah kabupaten melalui instansi terkait. 


\section{UCAPAN TERIMAKASIH}

Atas terselenggaranya penelitian ini kami mengucapkan terimakasih kepada Lembaga Penelitian dan Pengabdian Kepada Masyarakat Universitas Padjadjaran atas disetujuinya penelitian ini melalui program penelitian peneliti muda Unpad, kepada kepala Desa Pasireungit dan khusunya sekertaris desa bapak Iwan Gunawan dan juga berbagai pihak yang turut membantu kelancaran penelitian ini.

\section{DAFTAR PUSTAKA}

BPS (Badan Pusat Statistik) 2010. Jakarta

David, Fred R. 2004. Manajemen Strategi : Konsep-Konsep. Edisi Ketujuh. Indeks. Jakarta

Moehar, Daniel. 2005. Metode penelitian Sosial Ekonomi. Penerbit PT Bumi Aksara Jakarta.

PPK-LIPI. 2004. Ketahanan Pangan, Kemiskinan dan Demografi Rumah Tangga. Seri Penelitian PPK-LIPI No.56/2004. Jakarta. Puslit Kependudukan -LIPI

Rencana Pembangunan Jangka Menengah Desa (RPJMDes). 2007. RPJM Desa Pasireungit periode 2007-20013

Rangkuti, F. 2000. Analisis SWOT dalam Membedah Kasus Bisnis, Gramedia. Jakarta

Siregar, Faisal O. 2010. Analisis Strategi Pengembangan Usaha Kecil Keripik Pisang "Kondang Jaya" Binaan Koperasi Bmt Al-Ikhlaash Kota Bogor. IPB

Undang-Undang Republik Indonesia No 13 Tahun 2003 Tentang Ketenagakerjaan

Yuspita, M.H. 2004. Analisis Strategi Pengembangan Agroindustri Keripik Pisang Lampung. Jurusan Sosial Ekonomi Pertanian Universitas Padjadjaran. 